\title{
Modelling energy metabolism of Friesians in Kenya smallholdings shows how heat stress and energy deficit constrain milk yield and cow replacement rate
}

\author{
J. M. King ${ }^{1 \dagger}$, D. J. Parsons ${ }^{2 \ddagger}$, J. R. Turnpenny ${ }^{3}$, J. Nyangaga ${ }^{4}$, P. Bakari ${ }^{5}$ and C. M. Wathes ${ }^{2 \S}$ \\ ${ }^{1}$ clo DFID Livestock Production Programme, Natural Resources International Ltd, Park House, Bradbourne Lane, Aylesford, \\ Kent ME20 6SN, UK \\ ${ }^{2}$ Silsoe Research Institute, Wrest Park, Bedford MK45 4HS, UK \\ ${ }^{3}$ Tyndall Centre for Climate Change Research and CSERGE, School of Environmental Sciences, University of East Anglia, \\ Norwich NR4 7TJ, UK \\ ${ }^{4}$ International Livestock Research Institute, PO Box 30709, Nairobi 00100, Kenya \\ ${ }^{5}$ District Livestock Production Office, PO Box 553, Kilifi, Kenya
}

${ }^{\dagger}$ Present address: PO Box 1315, Village Market 00621, Nairobi, Kenya. E-mail: johnking@africaonline.co.ke

‡ Present address: Cranfield University, Silsoe, Bedford, MK45 4DT, UK

§ Present address: Royal Veterinary College, University of London, Hawkshead Lane, North Mymms, Hatfield, Herts, AL9 7TA, UK.

\begin{abstract}
The 2002 World Summit on Sustainable Development focussed attention on agricultural sustainability and biodiversity in developing countries. These goals are relevant for livestock production in Kenya, where development agencies encourage resource-poor smallholders to acquire large, exotic, high-yielding dairy cows, despite their poor performance, revealed in recent surveys in the highlands and at the coast. The performance of the cows is not in question. The debate relates to the diagnosis of the causes, their treatment and the prognosis for the production system. To improve our understanding of the dynamics of the system, models of nutrition and energy, modified for the tropics, were used to measure the thermal responses over $24 \mathrm{~h}$ of six pure or crossbred Friesians at a mean lactation of 54 (s.d. 21.6) days, in separate zero-grazing units. Four smallholdings were on the hot, humid coast and two in the cooler highlands. The output of the model runs was related to the subsequent lactation, calving interval and profitability of the cows. The model showed that the thermal load caused moderate stress for all cows during the day, which became severe in the sun in the highlands, but the drop in air temperature, from $27^{\circ} \mathrm{C}$ to $13^{\circ} \mathrm{C}$, at night dissipated the gain in body heat. At the coast, where the night temperature remained above $24^{\circ} \mathrm{C}$ and relative humidity above 0.85 , there was no remission of heat stress for cows with a milk yield greater than $11 /$ day. The lactation curve, in all cows, declined from an initial peak to a low profile of $5 \mathrm{l} /$ day. Cows in both regions with initial yields above 20l/day had the steepest decline and longest calving intervals (457 to 662 days). They had the largest lactation yields and lowest direct cost per litre, but their poor breeding record reduced cull sales and increased replacement cost, raising the total cost per litre. By contrast, the cow with the lowest daily and lactation yield had the highest direct cost, but lowest total cost per litre, because she produced 2 heifer calves at an interval of only 317 days. These case studies serve as a reminder that, where heat load depresses appetite or poor food cannot support lactation, the energy deficit and stress reduces cow fertility, fitness, and longevity, so that she fails to breed a heifer replacement during her shortened productive life. The model predicted that food intake, depressed by heat stress, would not support a milk yield above 14l/day and 3000 l per annum at the coast, and 22 I/day and 5000 I per annum in the highlands. Therefore, although appearing profitable in the short term, the current policy of promoting cows with higher yields than the climate and production system can support, is unsustainable. This outcome has implications for smallholder dairy development policy in Kenya, and probably elsewhere in the tropics. Instead, one should reconsider smaller exotic breeds and crossbreds with improved indigenous dairy cows whose overall productivity from milk yield, fecundity, longevity, and disease tolerance 50 years ago was better than that of the modern Holstein-Friesian in a Kenya smallholding.
\end{abstract}

Keywords: dairy cows, development policy, small farms, tropical Africa. 
King, Parsons, Turnpenny, Nyangaga, Bakari and Wathes

\section{Introduction}

The primary Millennium Development Goal of the United Nations (UN) is to halve the proportion of the world population living in extreme poverty by 2015 , particularly in SubSaharan Africa where it has remained at 50\% since 1990 (UN, 2005). In Kenya, for example, the agricultural wage is less than a dollar per day, and poverty on the coast affects nearly half of rural households (Nicholson et al., 1999). Milk production is seen as a way of increasing the standard of living of these poor farmers. Kenya has a culture of milk consumption and a recent history of successful commercial dairy farms (Chamberlain, 1993). It is well placed to exploit smallholder dairying, which has become the main livelihood of more than 600000 farms (Omore et al., 1999).

The current breed of choice for Kenyan small, zero-grazing units is the Holstein-Friesian. In Britain, these cows, routinely producing $>10000 \mathrm{I}$ of milk per lactation, are said to maximize profit with few animals, enhance production efficiency and nutrient optimization, and reduce environmental concerns about waste (Taylor et al., 2003). However, the high fixed costs and associated depreciation of British dairying, requiring economies of scale in terms of the size of both herd and cow (Webster, 1993), are irrelevant for Kenya smallholders. For them, the main expense is supplementary feeding, and the main workload is cutting and carrying forage, and fetching water (Van der Valk, 1992). Therefore, technical recommendations favour smaller breeds (Bebe et al., 2003a). The choice of the Friesian is explained in terms of its commercial attributes of highest milk yield in a market where payment is based on volume, and highest cull value based on heaviest weight (Kahi et al., 2000), plus some non-market attributes (Bebe et al., $2003 \mathrm{~b})$. However, close scrutiny of five surveys of dairy smallholdings in three districts in the Kenyan highlands between 1996 and 2000 (e.g. Bebe et al., 2003b; Staal et al., 2003), does not clarify how the breed's performance justifies its promotion. For example, the mean annual milk yield of smallholder cows, which were mainly Friesians, was only $1525 \mathrm{I}$. Nearly all the profit realized came from culled animals, but animal sales and deaths exceeded births in all the surveys. Confirmation that the herds are not self sustaining, was strongest in the most intensive dairying area where the cow replacement rate was 0.5 , i.e. one heifer or cow was available to replace every two cows leaving the herd (Bebe et al., 2003b). At the Kenyan coast, the average annual milk yield from Friesians in smallholdings (Waithaka et al., 2003) was even lower than in the highlands, at 1050 I, and the average mortality rate higher, at $56 \%$ to 18 months of age (Maloo et al., 2001a). The poor performance can be partially attributed to poor quality forage cut on the roadsides, which also brought in tick-borne diseases (Maloo et al., 2001b). Heat stress was not mentioned in the surveys, but is another constraint to which lactating Friesians are particularly susceptible (Rodriquez et al., 1985), leading to depressed food intake and milk production (Johnson, 1965). The hot, humid climate on the coastal lowlands is constantly above the comfort zone of lactating, exotic, dairy cattle (Ikiror, 2001) and is predicted to become $2^{\circ} \mathrm{C}$ warmer and $20 \%$ wetter by 2050 (Hulme et al., 2001).

This review of recent research suggests that the choice of high-yielding dairy cows for resource-poor, tropical smallholdings cannot be explained by their performance. Therefore, their continued promotion must be based on the assumption that the environment and system can and will support their high genetic merit for milk production. The purpose of this study is to examine if such an assumption is justified.

\section{Material and methods}

General design and location

To test if the high-yielding cow can express her potential, six individuals in separate zero-grazing units were studied in detail for $24 \mathrm{~h}$, using new models of animal energy and nutrition, modified for the tropics. The models were validated against physiological measurements, and then used to demonstrate the presence of stress and to predict the effect of reducing heat load and improving nutrition and milk yield. The cows were multiparous and at a mean lactation stage of 54 (s.d. 21.6) days. They were revisited 12 and 24 months later to record their subsequent lactation, calving performance and profitability.

Four of the case studies were done in the hot, humid, coastal, District of Kilifi (circa $3^{\circ} 40^{\prime} \mathrm{S}, 39^{\circ} 40^{\prime} \mathrm{E}$ ) in the coconut-cashew-cassava agro-ecological zone (Nicholson et al., 1999), at an altitude of about $40 \mathrm{~m}$. Two were done in the temperate highland District of Kikuyu (circa $1^{\circ} 10^{\prime} \mathrm{S}, 36^{\circ} 40^{\prime} \mathrm{E}$ ) in the horticulture-dairy zone (Bebe, 2003), at an altitude of $1875 \mathrm{~m}$. The initial fieldwork was done in 2003, between January and March, when the temperature-humidity-index is at its highest (Ikiror, 2001). The breed of choice was Friesian, but, at the coast during the hot season, only 3 out of $>60$ Friesian dairy cows were found to be in early lactation, and only one was on a smallholding. Therefore, three of the cows at the coast had some zebu blood, although they looked like Friesians.

\section{Models}

In order to simulate the nutrition and thermal responses of dairy cows, a system model, originally developed to investigate the impacts of climate change on dairy cows in temperate countries (Parsons et al., 2001), was modified to suit the smallholder zero-grazing system in Kenya and the available data. The original model had four components: grass production, nutrition and metabolic heat production, thermal responses of the animal, and thermal response of the building. The grass production model was irrelevant for the cut-and-carry system. The building model was also unnecessary, because the data included measurements of the microclimate in the cowshed. Furthermore, the actual diets consumed by the animals were recorded, so the nutritional model did not need to predict intake. The resulting system model had two remaining components, which will be outlined below: a simplified nutrition model and the model of the animal's thermal responses.

The nutrition model is based on Agricultural and Food Research Council (AFRC, 1993) and considers energy only, treating each day as a single period. It uses the factorial approach, estimating the energy needed for maintenance, growth, milk production and pregnancy. These are converted to metabolizable energy (ME) requirements in the food by the application of efficiency factors. For this study, the requirements of pregnancy could be neglected. The milk yield was measured and the model treats maintenance as dependent 
on weight only, so the sum of their ME requirements is the total ME that must be supplied. The difference between this requirement and the ME content of the diet is then expressed through weight change, with different efficiencies for deposition and mobilization of body fat reserves. The original model used separate ME contents for forage and concentrate foodstuffs and balanced them to meet the energy requirements of the cow, within a total voluntary intake, estimated by the model from live weight and milk yield. This mechanism was not required, because the actual intake of both components was recorded and converted into inputs to the model. Similarly, the actual milk yield was used as an input, instead of being estimated from a lactation curve.

The only departure from AFRC (1993) is the use of it to calculate heat production instead of energy requirements. Metabolic heat production is calculated as the total ME consumed, less the energy deposited in milk and body fat, using the equation:

$$
Q=E_{m}+E_{g}\left(1-k_{g}\right)+E_{p}\left(1-k_{p}\right)+E_{l}\left(1-k_{l}\right)
$$

where $E$ is energy requirement, $k$ is conversion efficiency and subscripts $m, g, p$ and I denote maintenance, growth, pregnancy and lactation respectively. The derivation of the energy requirements from mass, growth rate (which may be negative), stage of pregnancy, milk yield and butterfat content are given in AFRC (1993).

The energy used for maintenance and the excess energy required, due to the inefficiency of conversion from dietary ME or mobilized fat, have to be dissipated. Therefore, metabolic heat production is used as an input to the thermal balance model. It is assumed that the rate of heat production is constant throughout the day. In this version of the system, the interaction is only between the two sub-models, and, because it only considers a single day with the inputs fully determined, there is no feedback from the thermal model to the nutrition model to adjust appetite.

In order to predict the level of thermal stress suffered by the cattle, a mathematical model of the energy balance of homeotherms (Turnpenny et al., 2000a and b) was adapted for Kenyan conditions. The model was based on the physics of heat and moisture transfer and, as far as possible, avoided empirical representations. This allowed the model to be transferable to other climates and breeds. It was designed to run with a long series of readily available hourly weather variables as input data. The model works by trying to balance heat production with the sensible and radiant heat loss determined by the environment. Physiological responses to increasing environmental temperature are modelled sequentially as vasodilation on the trunk, then sweating. Since the model was designed to flag incidences of stress, rather than simulate the physiology during stress, the animal's body temperature was assumed constant. Stress levels were determined by the rate of sweating, which was defined as 'moderate' when the rate of sweating was half the physiological maximum, and 'severe' when it reached the maximum (Turnpenny, 1997).

Most of the parameters were those used for UK conditions, except that coat depth was taken as $1.0 \mathrm{~mm}$ and coat albedo as 0.1 (black). The minimum tissue resistance on the trunk might be expected to be lower for cattle in the tropics, because they have less subcutaneous fat. However, this value is not easily measured and heat loss is not particularly sensitive to this parameter. For example, reducing the value from $30 \mathrm{~s} / \mathrm{m}$ to $10 \mathrm{~s} / \mathrm{m}$ resulted in a reduction in evaporative heat loss of only $8 \%$. Therefore, the UK value was assumed in the absence of more robust data.

\section{Model data preparation}

Cow energy requirements were derived from weigh-band weight, daily milk yield, and butterfat, from a morning milk sample analysed at the Kenya Agricultural Research Institute (KARI), Mtwapa. The weigh band was calibrated for Friesians, and appeared to be less reliable at predicting the weight of the Boran zebu $\times$ Friesian crossbreds. It gave the tallest and longest (poll to tail head) of the six cows (Chonyi 1) the lowest weight. Chonyi 1 was estimated to be $100 \mathrm{~kg}$ less than the other Boran/Friesian crossbred (Chonyi $2)$, which was the shortest in height and length; yet both had the same condition score (3).

Food intake was measured on the same day as milk yield, but assumed to be the same as on previous days, which may not have been the case. For example, at Tezo and Kikuyu 2, the cows were disturbed by the hourly data collection, even though they were not handled, and at Mtwapa, the cow was given $5.5 \mathrm{~kg}$ more maize meal than she could eat. At the five other farms, fine feed was only given at the morning and evening milking. Fresh forage took up to $5 \mathrm{~h}$ to cut and carry in the morning, and was feed in portions so that refusals could be cleaned out and the trough replenished. For each feeding event during the $24 \mathrm{~h}$, the feed offered and that refused was identified, weighed separately, samples oven dried, and given an ME value from published and local records at KARI (Muinga et al., 1998) (Table 1).

Table 1 Food intake record over $24 \mathrm{~h}$ for cow at Kikuyu 1

\begin{tabular}{llcccc}
\hline \hline Food event & \multicolumn{1}{c}{ Food item } & Offered $(\mathrm{kg})$ & Refused $(\mathrm{kg})$ & $\mathrm{DM}^{\dagger}(\mathrm{g} / \mathrm{kg})$ & $\mathrm{ME}^{\dagger} \mathrm{MJ} / \mathrm{kg} \mathrm{DM}$ \\
\hline 1 & Dairy meal & 1.40 & 0.00 & 860 & 7.74 \\
1 & Napier grass, wilted, chopped fine & 15.20 & 3.75 & 176 & 8.95 \\
2 & Sweet potato vines, fresh intact & 5.25 & 0.00 & 106 & 8.08 \\
2 & Calliandra twigs, fresh intact & 5.25 & 0.00 & 219 & 9.00 \\
2 & Napier grass, wilted, chopped fine & 1.75 & 1.75 & 176 & 8.95 \\
3 & Food mixture, dry ration & 4.00 & 0.50 & 862 & 7.87 \\
4 & Dairy meal & 1.00 & 0.00 & 860 & 7.74 \\
5 & Kikuyu grass, yellow in warm bag & 11.25 & 0.00 & 262 & 8.16 \\
5 & Assorted weeds & 3.75 & 0.00 & 189 & 8.16 \\
\hline \hline
\end{tabular}

${ }^{\dagger} \mathrm{DM}=$ dry matter. $\mathrm{ME}=$ metabolizable energy. 
A biometeorological data set was collected 17 times (s.d.1.6) during the $24 \mathrm{~h}$, and took about $20 \mathrm{~min}$ to complete on each occasion. A Kestrel 3000 Environmental Meter (Richard Paul Russell Ltd, 26 Bankhill Drive, Lymington, Hampshire SO41 9FF, UK) was used to measure dry bulb air temperature (to $\pm 1.0^{\circ} \mathrm{C}$ ), relative humidity (to \pm 0.03 ), and moving, 3-s average, air speed (to $\pm 3 \%$ ) at cow height $(1.2 \mathrm{~m})$ inside the shed, and also at $2.0 \mathrm{~m}$ height outside to check for obstruction of air flow. A wind direction indicator was used to improve the 'on-axis' accuracy of the Kestrel Meter, and compass bearings taken of the openings of the shed in relation to the prevailing NE wind. Global solar radiation was measured in the one cowshed with an open central yard, using a Skye Pyranometer SP1100 (Skye Instruments Ltd, Unit 21, Ddole Industrial Estate, Llandrindod Wells, Powys LD1 6DF, UK) and cloud cover estimated in octas to compare ceiling temperatures under sun and cloud. The overall radiant temperature in the shed $\left(T_{r}\right)$ is derived from the mean of the thermal infra-red radiation emitted by walls, ceiling and ground, weighted by relative area of each of these parts as 'seen' by the animal:

$$
T_{r}^{4}=W_{\text {roof }} T_{\text {roof }}^{4}+W_{\text {walls }} T_{\text {walls }}^{4}+W_{\text {ground }} T_{\text {ground }}^{4}
$$

where $T_{\text {roof }}, T_{\text {walls }}$ and $T_{\text {ground }}$ are the measured radiant temperatures of the respective surfaces. $W$ in each case is the angular fraction of the total $360^{\circ}$ angle which each shed part contributes to the animal's 'view', as calculated from the shed dimensions. A solid-angle calculation was not deemed proportionate for this analysis due to the size and variable construction of the different buildings. The average of three spot temperatures (to $\pm 1.0^{\circ} \mathrm{C}$ ) on each room surface was taken with a hand held, non-contact, infrared thermometer 'gun', aimed with a laser beam (Oakton InfraPro 3, Oakton Instruments, Vernon Hills, Illinois, USA). At least three sides of the shed were open, with a few horizontal poles to contain the cow, and here, the wall temperature was equivalent to the air temperature. The fourth side usually contained the calf behind a solid partition. The concrete floor was rectangular with a mean area of 17.1 (s.d. $5.27) \mathrm{m}^{2}$. Flat corrugated metal roofs were supported on posts at a mean height of 2.3 (s.d. 0.53 ) $\mathrm{m}$ in front, and 2.1 (s.d. 0.56) $\mathrm{m}$ behind. Pitched roofs of palm thatch were supported at a height of $1.7 \mathrm{~m}$ (s.d. 0.07) at the sides, and raised to 3.2 (s.d. 0.25 ) $\mathrm{m}$ at the ridge.

Cow coat temperature was also taken every hour to compare with that predicted by the model. The average of single spot readings from the shoulders, abdomen and hindquarters, on the back and both sides, was taken every hour, using the infrared thermometer. The activity, attitude and long axis of the cow in relation to the room was also noted, as well as the respiration rate for signs of hyperthermia. None of these measurements disturbed the cow, which was only handled when the rectal temperature was taken after milking.

\section{Model runs}

A baseline run of the model, simulating a 24-h period, was performed for each cow. The nutritional model output for the day was: ME requirement for maintenance and lactation, percentage of ME supplied by the diet, and metabolic heat produced. The thermal balance model gave hourly outputs of coat temperature and stress level, graded mild, moderate and severe. Additional runs, to predict if there was a ceiling to daily milk yield, were performed with reduced environmental heat load, redressed energy imbalance, and raised milk yield with improved nutrition.

\section{Lactation curves and annual milk yield}

Lactation curves were fitted, by eye, to three or four records of daily milk yield for each cow at the start, first third, and end of lactation, using the equation of Wood (1969) or Plaizier et al. (1999), whichever gave the best fit. Wood's equation was designed to fit the curve that characterizes intensive milk production in temperate countries:

$$
y=a t^{b} e^{-c t}
$$

where $y$ is $\mathrm{kg}$ or $\mathrm{l} / \mathrm{day}, t$ is months since calving, a scales the curve up and down without changing the shape, $b$ controls the initial rise, and $c$ controls the decay from the peak. It was used to predict the temperate lactation curve shape $(b=0.49, c=0.232)$, with the level ' $a$ ' set in the highlands at 26.5 , and at the coast at 15.8 . The equation was also suitable for lactations that declined gradually, namely Chonyi $2(a=16.8, b=0.001, c=0.11)$ and Tezo $(a=15$, $b=0.2, c=0.33$ ). It did not fit curves with an initial steep fall, because later in the lactation it predicted a daily yield below that obtained. Such curves were better described by the logarithmic equation of Plaizier et al. (1999):

$$
y=h-s \ln (t)
$$

where $t$ is months since calving, $h$ dictates the height of the curve and $s$ the slope, namely those of Kikuyu $1(h=20 \cdot 2$, $s=5 \cdot 6)$, Kikuyu $2(h=16 \cdot 8, s=4.8)$, Mtwapa ( $h=27$, $s=9.5)$ and Chonyi $1(h=14.5, s=3.9)$. The lactation yield was estimated from the area under the curve, then divided by the calving interval and converted to annual milk yield.

\section{Budget analysis}

The main components are shown in Table 2. The calculations were based on those of the Kenya National Dairy Development Project (Van der Valk, 1992), except that family labour was charged at $80 \%$ of the agricultural wage (Staal et al., 2003), and the 'herd' was not assumed to be in long term equilibrium. Therefore, calving, mortality, buying and selling rates were obtained from each smallholding, and checked against the model of demographic rates (Bebe, 2003). The balance from direct costs of milk production, cow replacement cost and revenues from cattle cull sales, divided by litres of milk that could be sold, gave the cost per litre of milk, which was compared with the price obtained.

\section{Results}

Model validation

The hourly outputs of mean coat temperature from the model were compared with the mean values of the readings taken on the cow (Figure 1). In the highlands, the model prediction was normally within $1 \mathrm{s.d}$. or $1^{\circ} \mathrm{C}$, and always within 2 s.d., of the observed coat surface temperature, whereas, at the coast, it was approximately $2 \mathrm{s.d}$. or $2^{\circ} \mathrm{C}$ 
Modelling energy metabolism of Friesians in Kenya smallholdings

Table 2 Cost-price ${ }^{\dagger}$ of milk production on dairy smallholdings with a single cow and calf ${ }^{\neq}$

\begin{tabular}{|c|c|c|c|c|c|c|}
\hline \multirow[b]{3}{*}{ Farm } & \multicolumn{6}{|c|}{ Location } \\
\hline & \multicolumn{4}{|c|}{ Kenya coast } & \multicolumn{2}{|c|}{ Kenya highlands } \\
\hline & Chonyi 1 & Chonyi 2 & Tezo & Mtwapa & Kikuyu 1 & Kikuyu 2 \\
\hline \multicolumn{7}{|l|}{ Factor costs } \\
\hline Labour & 9600 & 9600 & 2727 & 8000 & 8000 & 8000 \\
\hline Land & 1500 & 1500 & 1500 & 1500 & 1500 & 1500 \\
\hline Capital interest & 2678 & 3009 & 3411 & 2616 & 2656 & 2948 \\
\hline Capital depreciation & 1440 & 1200 & 576 & 2160 & 2160 & 2160 \\
\hline \multicolumn{7}{|l|}{ Non factor } \\
\hline Fine feed & 18820 & 22056 & 8889 & 25897 & 15292 & 19632 \\
\hline Minerals & 1760 & 1320 & 945 & 1760 & 1760 & 1760 \\
\hline Health care & 5100 & 5185 & 2500 & 5185 & 4700 & 4700 \\
\hline Materials & 4130 & 3980 & 3500 & 4630 & 4630 & 4630 \\
\hline Grown forages & 4500 & 2200 & 2200 & 4500 & 4500 & 4500 \\
\hline COST per cow per annum & 49528 & 50050 & 26248 & 56248 & 45198 & 49830 \\
\hline Sale milk (I) & 2816 & 2754 & 1155 & 3450 & 2751 & 2512 \\
\hline Cost per I & 17.59 & 18.17 & $22 \cdot 73$ & $16 \cdot 30$ & $16 \cdot 43$ & $19 \cdot 84$ \\
\hline HERD male sale & 2287 & 2703 & 2886 & 2153 & 2475 & 2772 \\
\hline Replace per cow & -3040 & -80 & $6640^{\| 1}$ & -5600 & -6800 & -2000 \\
\hline Change in value & -753 & 2623 & 9526 & -3447 & -4325 & 772 \\
\hline Value per I & -0.27 & 0.95 & 8.25 & -1.00 & -1.57 & 0.31 \\
\hline Total cost per I & $17 \cdot 86$ & $17 \cdot 22$ & 14.48 & $17 \cdot 30$ & 18.00 & 19.53 \\
\hline Price per I & $20 \cdot 17$ & $18 \cdot 13$ & $18 \cdot 50$ & $40 \cdot 00$ & 21.50 & $25 \cdot 00$ \\
\hline Revenue per $\left.\right|^{\S}$ & $19 \cdot 90$ & 19.08 & $26 \cdot 75$ & 39.00 & 19.93 & $25 \cdot 31$ \\
\hline Profit per I & $2 \cdot 31$ & 0.91 & 4.02 & $22 \cdot 70$ & 3.50 & 5.47 \\
\hline
\end{tabular}

${ }^{\dagger} \mathrm{KSh}$, where $\mathrm{KSh} 76=\mathrm{US} \$ 1.00$.

${ }^{\ddagger}$ Calculation from Van der Valk (1992), adapted to Staal et al. (2003), with herd trades according to farmer and checked against model of demographic rates (Bebe, 2003).

$\S$ Revenue accrues from sale of milk and animals.

"Produced heifers surplus to cow replacement requirement.

below. The latter discrepancy may be due to the model assumption of a constant core temperature of $38^{\circ} \mathrm{C}$, whereas cattle raised their core temperature during the day (see Thermal load and heat stress). As a check, the model was rerun using, as an input, the observed variation in rectal temperature at Mtwapa, which was $38.9^{\circ} \mathrm{C}$ after morning and $39.5^{\circ} \mathrm{C}$ after evening milking. The prediction of coat surface temperature was improved by about $1^{\circ} \mathrm{C}$, bringing most of the predicted values to within 1 or $2 \mathrm{~s}$.d. of the observed.

\section{Thermal load and heat stress}

In all six zero-grazing units, the thermal load was high for lactating dairy cattle (Table 3). At the coast during the day, the ambient air temperature rose dramatically, with radiant heat

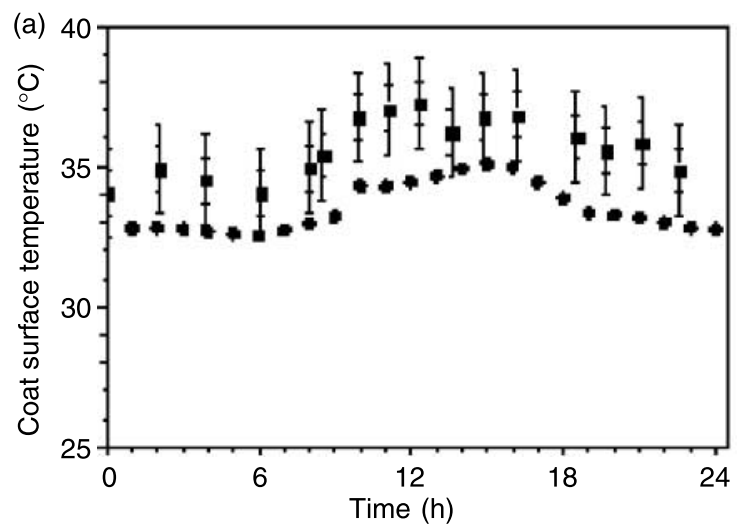

load even higher in sheds with corrugated metal roofs, where the ceiling temperature reached $58^{\circ} \mathrm{C}$, compared with $34^{\circ} \mathrm{C}$ under thatch. Values for the temperature humidity index rose as high as 84 , which is considered dangerous for high yielding Holsteins (Johnson et al., 1963).. The buildings were open sided but there were too many trees and huts between the cow shed and the sea breeze. Therefore, the onshore breeze failed to provide the expected cooling effect, because it was reduced to $<1 \mathrm{~m} / \mathrm{s}$ inside the cowsheds, from a maximum of $3 \mathrm{~m} / \mathrm{s}$ along the littoral at midday. There was slight remission of heat load at night, but conditions were humid and still, and ambient temperature remained above the upper critical temperature $\left(21^{\circ} \mathrm{C}\right)$ at which milk yield is depressed (Thatcher, 1974). In the highlands, the Index reached 73 by mid afternoon; a level which is associated

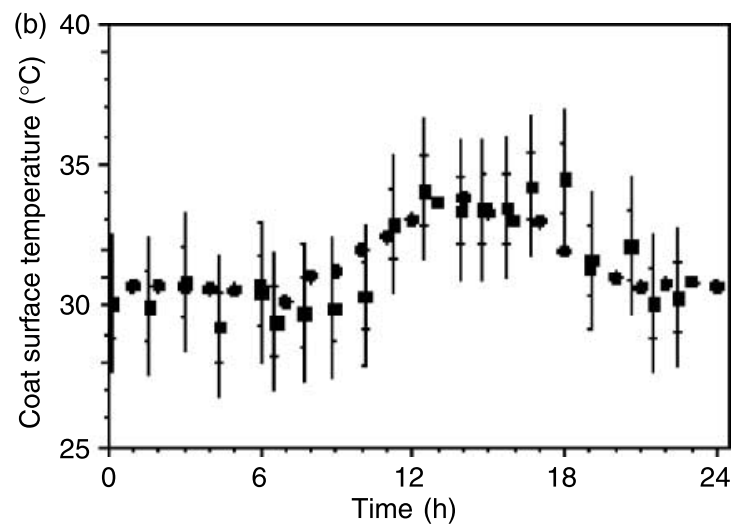

Figure 1 Mean coat surface temperature of cow $(\square)$ in metal-roofed zero-grazing unit during 24-h study compared with that predicted by the model ( $\bullet$ ), (a) on coast at Mtwapa, and (b) in highlands at Kikuyu 1. Observed mean is from nine readings, with error bar of 1 and 2 s.d. 
King, Parsons, Turnpenny, Nyangaga, Bakari and Wathes

Table 3 Diurnal extremes of thermal environment in zero-grazing units

\begin{tabular}{|c|c|c|c|c|c|c|}
\hline \multirow{4}{*}{$\begin{array}{l}\text { Roof type } \\
\text { Farm }\end{array}$} & \multicolumn{6}{|c|}{ Location } \\
\hline & \multicolumn{3}{|c|}{ Kenya coast } & \multicolumn{3}{|c|}{ Kenya highlands } \\
\hline & \multicolumn{2}{|c|}{ Ridged palm thatch } & \multicolumn{4}{|c|}{ Flat corrugated metal } \\
\hline & Chonyi 1 & Chonyi 2 & Tezo & Mtwapa & Kikuyu 1 & Kikuyu $2^{\dagger}$ \\
\hline \multicolumn{7}{|l|}{ Dawn } \\
\hline T air $\left({ }^{\circ} \mathrm{C}\right)$ & 24.4 & $25 \cdot 0$ & $24 \cdot 3$ & $25 \cdot 6$ & $15 \cdot 2$ & 11.3 \\
\hline $\mathrm{T}$ radiant $\left({ }^{\circ} \mathrm{C}\right)$ & $25 \cdot 2$ & $25 \cdot 9$ & $24 \cdot 0$ & $24 \cdot 8$ & $15 \cdot 2$ & $9 \cdot 1$ \\
\hline Relative humidity & 0.91 & 0.85 & 0.89 & 0.90 & 0.77 & 0.85 \\
\hline \multicolumn{7}{|l|}{ Afternoon } \\
\hline T air $\left({ }^{\circ} \mathrm{C}\right)$ & $31 \cdot 8$ & 33.5 & $32 \cdot 6$ & 31.5 & $26 \cdot 8$ & $26 \cdot 8$ \\
\hline T radiant $\left({ }^{\circ} \mathrm{C}\right)$ & 31.1 & 31.7 & 41.9 & 36.9 & 31.8 & 26.5 \\
\hline Relative humidity & 0.56 & 0.50 & 0.63 & 0.61 & 0.42 & 0.33 \\
\hline
\end{tabular}

${ }^{\dagger}$ Centre of yard open.

with depression of milk yield and conception to first service (Du Preez et al., 1990). The heat load was particularly severe in Kikuyu 2, because the food trough was not shaded from solar radiation of up to $1100 \mathrm{~W} / \mathrm{m}^{2}$. However, at night, the ambient temperature drop exceeded $10^{\circ} \mathrm{C}$, to well below the upper critical temperature for lactation.

Model runs revealed that all six cows suffered from moderate or severe stress for at least $10 \mathrm{~h} /$ day (Table 4). At the coast, the observed mean rectal temperature after the dawn milking was 38.2 (s.d. 0.58$)^{\circ} \mathrm{C}$ and rose to 38.8 (s.d. 0.29$)^{\circ} \mathrm{C}$ after the evening milking. For three cows with a yield $>11 \mathrm{l} /$ day, moderate stress was continuous, with the highest yielder (Mtwapa, 18l/day) being on the verge of hyperthermia $\left(39.5^{\circ} \mathrm{C}\right)$ by the evening milking. In the highlands during the day, both cows showed moderate stress, which was severe in Kikuyu 2 when she stood feeding in the sun. However, their rectal temperatures dropped from 38.6 (s.d. 0.14$)^{\circ} \mathrm{C}$ in the evening to 37.4 (s.d. 0.14$)^{\circ} \mathrm{C}$ by dawn, which would allow their appetites to return (Scott et al., 1983).

\section{Feed and water intake}

Fine feeds constituted between a quarter and three quarters of the diet, and one-sixth to half of the cost of keeping the cow (Table 2). The amount of supplement depended on the availability of cash, forage, food crop by-products, grasses, and palatable 'weeds' (Table 5). Grass and weeds were gathered mainly off farm at the coast, where the labour of cutting and carrying took up to $5 \mathrm{~h} /$ day, and amounted to a tenth to a fifth of the total cost per cow. Despite the wide range of foodstuffs, there was limited scope to increase the mean energy density of the diet above 8.8 MJ ME per kg (compare Tables 4 and 5). There was no piped water on the smallholdings of Kikuyu 1 and Chonyi, so the women had to fetch and carry at least $60 \mathrm{I}$, per cow and calves, in 20 I containers on foot from up to $2 \mathrm{~km}$ away. Lack of water was not thought to depress milk production, compared with the other case studies.

\section{Daily and annual milk yield}

The daily yield of all six cows declined from a peak in the first fortnight to a low, stable profile, that is characteristic of Kenya smallholdings (Plaizier et al., 1999). Cows in each region with high initial yields of $>20 \mathrm{l} /$ day (Kikuyu 1, 2, and Mtwapa) had the steepest declines, longest lactations, largest lactation yields, and longest calving intervals (Figure $2 \mathrm{a}$ and $\mathrm{b}$; Table 6). Extended lactations, beyond the

Table 4 Principal input data and model outputs for single-day runs of nutrition and heat balance for six test cows on Kenya smallholdings

\begin{tabular}{|c|c|c|c|c|c|c|}
\hline \multirow{4}{*}{$\begin{array}{l}\text { Cow breed } \\
\text { Farm }\end{array}$} & \multicolumn{6}{|c|}{ Location } \\
\hline & \multicolumn{4}{|c|}{ Kenya coast } & \multirow{2}{*}{\multicolumn{2}{|c|}{$\begin{array}{c}\text { Kenya highlands } \\
\text { Friesian }\end{array}$}} \\
\hline & \multicolumn{2}{|c|}{ Boran $\times$ Friesian } & \multirow{2}{*}{$\begin{array}{c}\mathrm{Fr} \times \mathrm{SEAZ}^{\dagger} \\
\text { Tezo }\end{array}$} & \multirow{2}{*}{$\begin{array}{l}\text { Friesian } \\
\text { Mtwapa }\end{array}$} & & \\
\hline & Chonyi 1 & Chonyi 2 & & & Kikuyu 1 & Kikuyu 2 \\
\hline \multicolumn{7}{|l|}{ Input data } \\
\hline Live weight $(\mathrm{LW} ; \mathrm{kg})^{\ddagger}$ & 325 & 427 & 385 & 499 & 483 & 420 \\
\hline Milk yield (I) & 11.4 & $17 \cdot 0$ & $7 \cdot 3$ & $18 \cdot 0$ & $18 \cdot 3$ & $13 \cdot 0$ \\
\hline Butterfat $(\mathrm{g} / \mathrm{kg})$ & 34 & 56 & 42 & 37 & 35 & 36 \\
\hline Dry matter intake $(\mathrm{kg})$ & $12 \cdot 9$ & $15 \cdot 9$ & $7 \cdot 8$ & $17 \cdot 6$ & $17 \cdot 3$ & $12 \cdot 5$ \\
\hline DM intake (\% LW) & $4 \cdot 0$ & 3.7 & $2 \cdot 0$ & 3.5 & 3.6 & 3.0 \\
\hline ME density (MJ/kg) & $8 \cdot 1$ & 8.7 & 8.2 & 8.5 & 8.6 & $8 \cdot 2$ \\
\hline \multicolumn{7}{|l|}{ Outputs } \\
\hline ME availability $(\%)^{\S}$ & 96 & 83 & 66 & 96 & 97 & 82 \\
\hline Weight change (kg) & $-0 \cdot 17$ & -0.92 & $-1 \cdot 12$ & -0.17 & $-0 \cdot 16$ & -0.73 \\
\hline Moderate stress (h) & 24 & 24 & 10 & 24 & 10 & 7 \\
\hline Severe stress (h) & 0 & 0 & 0 & 0 & 0 & 4 \\
\hline
\end{tabular}

${ }^{\dagger} 7 / 8$ Friesian $\times$ Small East African Zebu.

${ }^{\ddagger}$ Derived from Friesian weigh band.

$\S$ Per cent of metabolizable energy needs supplied by diet. 
Modelling energy metabolism of Friesians in Kenya smallholdings

Table 5 Component density of cow dietary intake

\begin{tabular}{|c|c|c|c|c|c|c|c|}
\hline & \multirow{3}{*}{$\begin{array}{c}\text { Density } \\
\text { (MJ ME per kg DM) }\end{array}$} & \multicolumn{6}{|c|}{ Location } \\
\hline & & \multicolumn{4}{|c|}{ Kenya coast } & \multicolumn{2}{|c|}{ Kenya highlands } \\
\hline & & Chonyi 1 & Chonyi 2 & Tezo & Mtwapa & Kikuyu 1 & Kikuyu 2 \\
\hline \multicolumn{8}{|l|}{ Fine feed } \\
\hline Dairy meal & $7 \cdot 7$ & & & 9 & & & 16 \\
\hline Maize meal & $8 \cdot 1$ & 51 & 42 & 18 & 45 & 36 & 24 \\
\hline Wheat bran & $9 \cdot 0$ & & & & 71 & & \\
\hline \multicolumn{8}{|l|}{ Forage } \\
\hline $\mathrm{Crop}^{\dagger}$ & $9 \cdot 0$ & & 38 & & & & 10 \\
\hline Food by-product ${ }^{\ddagger}$ & $9 \cdot 7$ & 2 & 23 & & & 30 & 5 \\
\hline \multicolumn{8}{|l|}{ Grasses } \\
\hline Napier & 8.9 & & 14 & & & 62 & 18 \\
\hline Gathered $^{\S}$ & 8.2 & 23 & & 14 & 2 & 11 & 24 \\
\hline 'Weeds'" & $8 \cdot 2$ & 29 & 19 & 22 & 33 & 9 & 6 \\
\hline Total intake (MJ ME) & 105 & 136 & 63 & 150 & 148 & 103 & \\
\hline
\end{tabular}

Coast: ${ }^{\dagger}$ Leucaena. ${ }^{\ddagger}$ cassava leaf, sweet potato vine. napier. ${ }^{\S}$ digitaria, panicum.

" clitoria, commelina, double thorn, kizolaadzoma, mtandofu.

Highlands: ${ }^{\dagger}$ Calliandra. ${ }^{\ddagger}$ maize stover, sweet potato vine. ${ }^{\S}$ napier. ${ }^{\S}$ kikuyu grass.

"I not identified.

optimum lactation for northern Europe of 305 days, were not from choice, but due to the failure of cows to show oestrus or conceive. The coast farms used natural service, with Tezo and Mtwapa having their own bull. The highland smallholdings, used artificial insemination (Al). The Friesian (at Mtwapa) with the highest annual milk yield, failed to recover condition prior to her next (third) lactation, despite having an extended calving interval of 457 days. She gave birth to a tiny calf, and died with acute mastitis four days later, despite veterinary attention. By contrast, the cow (at Tezo) with the lowest milk yield had the least heat stress, and shortest lactation, because of a calving interval of only 317 days.

Cost-price of milk production per litre (in KSh, where KSh $76=$ US\$1)

Excluding niche markets, the mean annual price of milk (KSh 19.6 , s.d. 1.57) was only $5 \%$ above the direct milk cost (KSh 18.7, s.d. 2.75) (Table 6). Seasonally the price fell as low as KSh 16.0 (at Tezo). In both regions, the cow

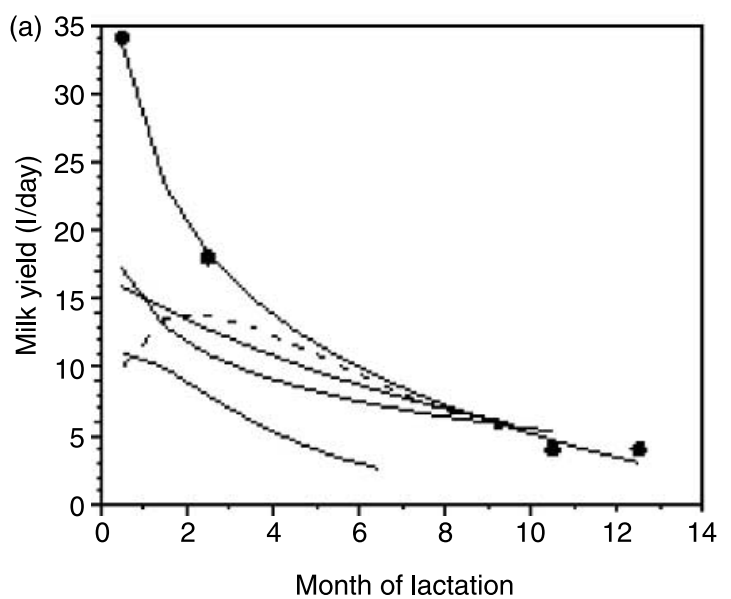

with the highest lactation yield had the lowest direct cost, but her poor breeding performance added as much as KSh 1.5 to the cost of herd trading, as provision for her replacement. The cow with the lowest lactation yield (Tezo) had the highest direct costs, despite low fine feed costs. However, the added value of producing two heifer calves within the year, for sale and replacement, offset the milk cost by KSh 8.2, to give the lowest total cost of milk and herd trade for the six smallholdings (Table 6). The two niche markets with high prices required higher butterfat than found in Friesian milk, which was mixed with Jersey milk prior to sale. Two of the three crossbred cows had high butterfat (Table 2), which can be attributed to their zebu blood (Anderson, 1935).

Predicted daily milk yield without stress and energy deficit The daily milk yield that can be supported by a feed intake from which the metabolic heat can be dissipated, was taken as the sustainable level. It was predicted as $<22 \mathrm{l} /$ day in the highlands and $<14 \mathrm{l} /$ day at the coast, and derived from

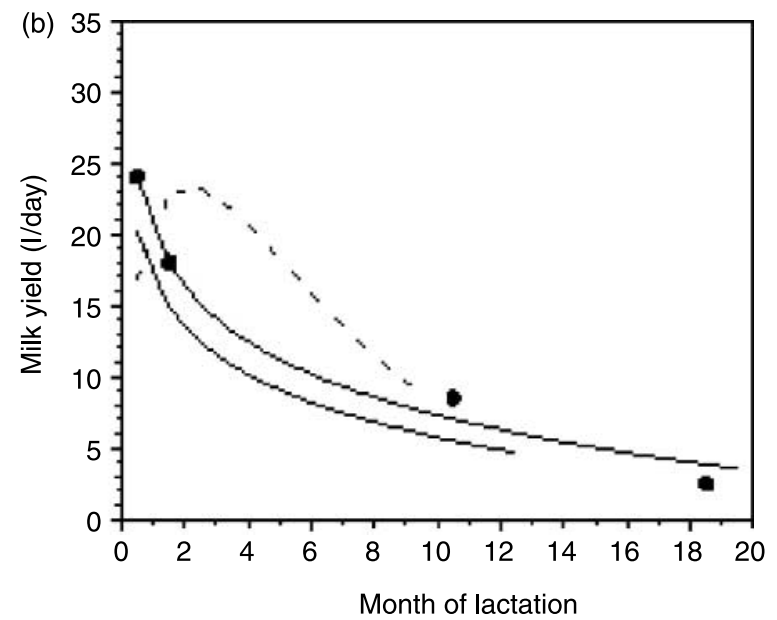

Figure 2 Optimal lactation curve for annual calving rate (dashed line), versus actual curves, (a) at coast, where highest is Mtwapa, showing data points $(\bullet)$, followed by Chonyi 2 , Chonyi 1 , and lowest, Tezo, and (b) in highlands, where Kikuyu 1 , showing data points $(\bullet)$, is higher than Kikuyu 2 
King, Parsons, Turnpenny, Nyangaga, Bakari and Wathes

Table 6 Low cost of high lactation yield offset by high cost of cow replacement

\begin{tabular}{|c|c|c|c|c|c|c|}
\hline \multirow{4}{*}{$\begin{array}{l}\text { Cow breed } \\
\text { Farm }\end{array}$} & \multicolumn{6}{|c|}{ Location } \\
\hline & \multicolumn{3}{|c|}{ Kenya coast } & \multicolumn{3}{|c|}{ Kenya highlands } \\
\hline & \multicolumn{2}{|c|}{ Boran $\times$ Friesian } & \multirow{2}{*}{$\begin{array}{c}\text { Fr } \times \text { SEAZ } \\
\text { Tezo }\end{array}$} & \multirow{2}{*}{$\begin{array}{l}\text { Friesian } \\
\text { Mtwapa }\end{array}$} & \multicolumn{2}{|c|}{ Friesian } \\
\hline & Chonyi 1 & Chonyi 2 & & & Kikuyu1 & Kikuyu 2 \\
\hline Lactation yield, I & 2945 & 3060 & 1365 & 4635 & 5355 & 3575 \\
\hline Calving interval, $d$ & $343^{\ddagger}$ & 370 & 317 & $457^{\S}$ & 662 & 468 \\
\hline Annual milk yield, I & $3100^{\ddagger}$ & 3020 & 1570 & 3700 & 2950 & 2790 \\
\hline Direct cost milk ${ }^{\dagger}$ & 17.6 & $18 \cdot 2$ & $22 \cdot 7$ & $16 \cdot 3$ & $16 \cdot 4$ & $19 \cdot 8$ \\
\hline Cost milk \pm herd trade ${ }^{\dagger \uparrow}$ & $17 \cdot 9$ & $17 \cdot 2$ & 14.5 & $17 \cdot 3$ & $18 \cdot 0$ & $19 \cdot 5$ \\
\hline Milk sale price ${ }^{\dagger}$ & $20 \cdot 2$ & $18 \cdot 1$ & $18 \cdot 5$ & $40 \cdot 0^{\| \prime}$ & 21.5 & $25 \cdot 0^{11}$ \\
\hline
\end{tabular}

${ }^{\dagger} \mathrm{KSh} / \mathrm{l}$, where $\mathrm{KSh} 76=\mathrm{US} \$ 1.00$.

₹ Abortion 246 days.

$\S$ Died 4 days post partum

"Mixed with Jersey milk.

$"$ "Herd trade $=$ cull sales - cow replacement cost.

model runs in which heat stress was reduced, nutrition improved, and milk yield raised.

For example, in the highlands the lower ME availability for Kikuyu 2 (Table 4), was attributed primarily to inadequate shade over the manger during the day, and lack of forage at night. To investigate the effects of adding shade, the model was run with direct and diffuse solar radiation inputs set to zero throughout the day. With all other inputs unchanged, the duration of moderate thermal stress was reduced from $7 \mathrm{~h}$ to $5 \mathrm{~h}$, and that of severe stress from $4 \mathrm{~h}$ to $0 \mathrm{~h}$. The DM intake was then raised to $15 \mathrm{~kg} /$ day, the same proportion of body weight as Kikuyu 1, which brought the ME availability to $98 \%$. It returned the duration of moderate stress to $7 \mathrm{~h}$, compared with $10 \mathrm{~h}$ in Kikuyu 1, and did not produce any severe stress. Increasing the milk yield to $15.9 \mathrm{l} / \mathrm{day}$, to match Kikuyu 1 on a pro rata body weight basis, reduced ME availability to $82 \%$, without raising the stress levels. Finally, increasing the ME density of the diet to $9.0 \mathrm{MJ} / \mathrm{kg}$, which would be difficult with the existing feedstuffs (Table 5 ), raised $\mathrm{ME}$ availability to $99 \%$, still with no increase in stress. The conclusion from these model runs is that this cow's productivity is being limited, in the first place by lack of shade while feeding during the day, and then lack of forage overnight. If these constraints were reduced, Kikuyu 2 should be able to achieve a performance comparable with Kikuyu 1.

The possibility of increasing the production of Kikuyu 1 was investigated by progressively raising the daily milk yield and increasing the ME density of the diet to maintain ME availability over $97 \%$. To increase the yield by $10 \%$ to $20 \mathrm{l} /$ day, at the time of the study in the second month of lactation, the energy density had to be increased to $9.3 \mathrm{MJ} / \mathrm{kg}$. The resultant stress levels, of $12 \mathrm{~h}$ of moderate but $\mathrm{Oh}$ severe stress, were considered acceptable, because there remained $12 \mathrm{~h}$ overnight for recovery. To reach a level of $22 \mathrm{l} /$ day, the energy density had to rise to $9.5 \mathrm{MJ} / \mathrm{kg}$, at which point moderate stress was present for $15 \mathrm{~h}$, but without severe stress. Raising the dietary energy density to an improbable 9.8 MJ ME per $\mathrm{kg}$, compared with the figures obtained in Tables 4 and 5 , increased the duration of moderate stress to $19 \mathrm{~h}$, but still with $\mathrm{Oh}$ severe stress. There seemed little point in taking the predictions further, given the sensitivity of the cow to heat stress and the limited availability of high quality, fine feed and supplements.

At the coast, little could be done to alleviate heat stress, beyond the provision of shade, preferably as thatch rather than corrugated metal. Increasing air speed from still to $1.5 \mathrm{~m} / \mathrm{s}$ resulted in only a $5 \%$ decrease in sweat rate. The relatively short duration of moderate stress at Tezo was attributed to low food intake (Table 4), because when DM intake was raised to $11.8 \mathrm{~kg}$ in the model, the duration of moderate stress increased to $23 \mathrm{~h}$. There was little scope to reduce the heat increment of feeding by increasing the quality of the diet, because of the low energy density of the weeds, grasses and fine feed that made up most of the diet (Table 5), and the lack of land for cultivating forage as opposed to food crops. At Mtwapa, which could afford fine feeds, the high-yielding cow was observed to be on the verge of hyperthermia. Therefore, the ceiling to daily milk yield had to be below 18l/day, and above the lowest value for continuous moderate stress of $11 \mathrm{l} / \mathrm{day}$, which did not extend the calving interval.

\section{Predicted lactation yield of a sustainable herd}

The optimal lactation curves, in Figure $2 \mathrm{a}$ and $\mathrm{b}$, had a yield of $3000 \mathrm{l}$ at the coast, and $5000 \mathrm{I}$ in the highlands. They were based on the following assumptions. The cow should calve once a year to ensure a heifer replacement, because of her short productive life and the high mortality rate of the herd (Bebe et al., 2003b). The lactation should be terminated at 300 days, because nutritional management before calving plays a critical rôle in the subsequent fertility of the cow. The daily milk yield at the start of lactation should not exceed the acceptable level predicted by the model, because nutrient shortage or stress is the primary cause of infertility post partum (Wathes et al., 2003). The bulk of the concentrates had to be fed in the first three months, to obtain the initial plateau in the lactation curve, instead of the current practice of feeding about $2 \mathrm{~kg} /$ day throughout the lactation (Romney et al., 2005).

A comparison of the actual and optimal lactation curves reveals that, at the coast, the steep decline in the high 
yielding curve can be attributed to daily milk yield exceeding the physical heat stress threshold. Whereas, in the highlands, steep declines below the threshold imply that the diet is inadequate, unless the threshold has been set too high.

\section{Discussion}

The issue

The disappointing performance of high-yielding dairy cows in Kenya smallholdings is not in question. The debate relates to the diagnosis of the causes, their treatment and the prognosis for the high-input production system. The outcome has implications for smallholder dairy development policy in Kenya, and probably elsewhere in the tropics. The model with its nutritional and thermal components was used to improve our understanding of the dynamics of the system. Six case studies from two agro-ecological zones, with a variety of grade and crossbred Friesians, were not expected to yield statistical comparisons. Nevertheless, they provided realistic scenarios and their diversity was considered an asset rather than a weakness, because they increased the range of inputs to the model.

\section{Constraints, causes and solutions}

Current thinking on smallholder dairy management is reflected in a paper by Omore et al. (1998), based on the highlands in Central Kenya, in which they highlight aspects of poor performance, attribute causes, and offer solutions. For example, low average milk production of 5 to $8 \mathrm{~kg} /$ day is attributed primarily to under nutrition, particularly during peak lactation, requiring adjustments to concentrate feeding, more crop by-products and road side fodder cultivation. The results from our case studies are largely in agreement with this evaluation. The average lactation yield of the highland case studies (Kikuyu 1 and 2) is similar ( $8 \mathrm{~kg} /$ day), as is the shape of their lactation curves (Plaizier et al., 1999). To convert the lactation to an optimal Wood's curve (Figure $2 \mathrm{~b})$ will require sufficient concentrates at the beginning of the lactation, which assumes that there is cash to purchase fine feed before milk sales have brought in sufficient revenue to do so. Therefore, farmers may need access to credit to improve the first third of the lactation.

The nutrition model takes the debate a stage further by predicting that it is probably unrealistic to attempt to achieve yields above 18l/day by incremental feeding, given the energy density of the available feed (Tables 4 and 5), so that higher yields will be obtained by depletion of the cow's energy reserves, generating less heat, but reducing body condition and fertility. The thermal model runs, supported by the biometeorological data, confirm that there was heat stress, even in the highlands, where it was severe for a Friesian standing in the sun, producing only $13 \mathrm{l} /$ day. That stress could be overcome by the provision of shade, but, at milk yields $>16 \mathrm{l} /$ day one has to accept moderate stress during daylight hours in the highlands. The breed of choice should not have a lactation yield $>22 \mathrm{l} /$ day, which is the thermal model maximum. This modest level of daily milk yield rules out most of the genetic material being promoted by international breeding services.
Long calving intervals, commonly of 600 days, were attributed to farmers not trying to breed before 200 days post partum (Omore et al., 1998). The calving intervals of the two highland case studies were 662 and 468 days, but not from lack of trying to get the cows in calf. So farmers may not be 'voluntarily' lengthening their calving intervals (Plaizier et al., 1999), so much as avoiding unnecessary expense from repeated, unsuccessful visits from the Al service. One cannot be certain, which interpretation is true until one has eliminated the commonest reason for infertility, which is the energy deficit (Wathes et al., 2003). Until that is corrected, current emphasis, on the provision of a better artificial insemination service or other aspects of infertility (De Rensis and Scaramuzzi, 2003; Taylor et al., 2003), will not be cost effective. To produce a calf per year, the lactation length should not exceed 300 days, giving a maximum annual yield under the optimum theoretical curve of $5000 \mathrm{I}$. This level looks optimistic compared with the estimate of 3400 I (Plaizier et al., 1999), so at this stage of development, cows of even lower genetic merit will be required to ensure good reproduction.

The case studies have little to add to the observation of Omore et al. (1998), that calf growth rate is low and mortality high, due lack of milk and diarrhoea, requiring better husbandry and animal health. Consequently, age at first calving is late and there is a shortage of own-produced cow replacements. Health in the cow was not considered a big problem, but the prediction that sub-clinical mastitis and lameness will become so when milk yields increase, was borne out by the death of the Friesian at Mtwapa with acute mastitis. Input services were considered inadequate, except in the large co-operatives near Nairobi. However, it is not clear, from the cost-price calculations in the case studies, how higher inputs could be financed by a low output system. The milk sale price in the case studies was only $5 \%$ above direct costs of KSh 17.9 per I, which is in agreement with KSh 17.2 per I in the extensive survey of Staal et al. (2003), so profitability is low. There is general agreement on the need to improve the infrastructure to facilitate market access. However, profitability will remain poor until the low output system of e.g. 3500 I per annum, is balanced by lower inputs than at present, namely, a less expensive zerograzing unit and cow, and cheaper husbandry and health package.

In less favourable dairying areas than the highlands, such as the coast, current thinking puts more emphasis on disease, which is also reflected in an increased cost of animal health care in three of the coastal case studies compared with the highlands (Table 2). Up to now, heat stress has been ignored, which is surprising given the length of time its effect on dairy cattle has been known (e.g. Johnson, 1965). It was at the coast, that the thermal model contributed most to our understanding of the low performance from highyielding cows. Moderate heat stress was present throughout the $24 \mathrm{~h}$ for cows with yields $>11 \mathrm{l} /$ day, even under shade (Table 4), and further attempts to adapt the habitat to the cow were unsuccessful or impractical. No amelioration of stress was observed in the cows under roofs of palm thatch, despite an afternoon radiant temperature of 31.4 (s.d. $0.42)^{\circ} \mathrm{C}$, compared with 39.4 (s.d. 3.54$)^{\circ} \mathrm{C}$ under corrugated 
metal (Table 3). The onshore breeze failed to reach the inside of the sheds, even though they were open-sided. It was not strong enough anyway, because air speed has to be more than $3 \mathrm{~m} / \mathrm{s}$ at animal height to have a significant cooling effect. At such high values for air temperature and humidity, some stress will always be present in lactating cattle, even in very high winds. Cooling with electric fans would be too expensive, and spraying is contraindicated in such a warm, humid environment, except as a measure to control disease (Macfarlane and Stevens, 1972). Besides, half the smallholdings had no power or water supply. Therefore, the emphasis should revert to adapting the cow to the habitat. The heat load is not life threatening, but where it is unremitting, it is sufficient to depress food intake and reproduction (e.g. Thatcher, 1974; Du Preez et al., 1990), which is why the sustainable level is predicted to be lower than in the highlands at only $14 \mathrm{l} / \mathrm{day}$ and $3000 \mathrm{I}$ per annum. Of course, that level can be exceeded, but at a cost that comes later. For example, the grade Friesian at Mtwapa gave $35 \mathrm{l} /$ day after calving, had a lactation yield of $4635 \mathrm{I}$, but a calving interval of 457 days. She then produced a stunted calf, and died 4 days into her third lactation (Figure 2a, Table 6).

\section{Prognosis}

Whereas Omore et al. (1998) state that, 'smallholder dairying is viewed by both farmers and development agencies as a promising avenue for rural poverty alleviation', the results from this study require the caveat: 'only if you change the breed of cow and the production system'. This warning is not popular with many farmers, development agencies or scientists.

\section{Popularity and problems of the high-yielding cow}

The initial performance of the high-yielding Friesians in the case studies, helps to explain their reported popularity with the smallholder. The cows with the highest daily and total lactation yields had the lowest direct cost per litre (Figure 2; Table 6). At the start of the lactation, the farmer's wife can deduct milk for home consumption and the cost of family labour, but still make a profit. The long term implications of the cow's low calving rate and shortened productive life should eventually become apparent to the farmer, probably before they do to the research and development team, who wonder why 'less than $1 \%$ of households have a grade cow at the coast, when each grade cow was reported to increase income by KSh 4000 per month, and despite ten years of Livestock Development and National Dairy Development Projects' (Nicholson et al., 1999).

The high-yielding cow is also popular with development agencies, because high daily and total lactation yields are easy to 'sell' to the uninformed. 'Sell' is the appropriate word where bilateral aid is associated with the purchase of goods (genetic material) from the donors, e.g. to the Kenya Dairy Development Project/Smallholder Dairy Project (2004). The findings of this study mean that 'such aid is of dubious quality' (Economist, 2005), and support the reservation that, latterly, there has been an over reliance on imported genetic material, mainly Holstein-Friesians from USA, UK, Canada and the Netherlands (Bebe, 2003).
The notion, that dairying is associated with black and white cows, is perpetuated by extension officers and animal scientists. Returning graduates and visiting researchers try and emulate the livestock production systems of the industrial "North" in which their science has evolved (WatersBayer and Bayer, 2004). They appear to have rejected one of the founding tenets of the International Livestock Research Institute, that the path of development for the livestock industry in many poor tropical countries will inevitably be very different from that which has evolved in the developed world (Rockefeller Foundation, 1994). Furthermore, by focussing on more milk, animal scientists may be tethering their enquiry to a version of dairy development, which may become obsolete even in Europe and North America. There, the average herd life of a dairy cow has decreased significantly since the 1980s. It is now only 33 months for Holsteins in Canada, with the most frequent reason for culling being poor reproductive performance. 'It is clear that net farm income could be significantly increased by increasing the herd life and number of lactations' (Margerison, 2003).

\section{Conclusion and recommendations}

A dairy development policy, which promotes exotic dairy cattle of higher genetic merit than the tropical climate and resource-poor smallholding can support, is creating problems that are difficult to solve. In order to ensure a sustainable herd, the potential daily milk yield of a smallholder cow should match the availability of food from which the metabolic heat of production can be dissipated. The ceiling to milk production at which the heat stress becomes unacceptable will vary with the microclimate and nutrition, but it is unlikely to exceed one-third of the genetic potential of a Friesian at the coast and one-half in the highlands. Given this low input/output system, the productivity of the smallholder dairy cow needs to be redefined in terms of making the most efficient use of scarce resources, such as ME (James and Carles, 1996), labour, capital and health services (Table 2), as well as providing non-marketed benefits (Bosman et al., 1997). When these criteria were applied to small ruminants, indigenous goats (Ayalew et al., 2003) and sheep (Baker et al., 2004) were reinstated above exotic introductions, as being more appropriate for smallholder farmers and pastoralists. A similar case can be made for indigenous cattle and their crossbreds with small exotic dairy breeds. The annual milk yield of dairy Boran, Nandi and Jiddu cows, under improved management 50 years ago (Faulkner, 1951; Mason and Maule, 1960 ), was similar to that of the modern Friesian in a Kenya smallholding, and their fecundity and longevity was considerably better.

\section{Acknowledgements}

We thank the Smallholder Dairy Project of the International Livestock Research Institute, Nairobi, the District Livestock Production Office, Kilifi and the Kenya Agricultural Research Institute, Mtwapa for their advice and support, and especially the smallholders of Kilifi and Kikuyu Districts for their collaboration. This work received funding support from the Department For International Development, Livestock Production Programme managed by Natural Resources International Limited. 


\section{References}

Agricultural and Food Research Council. 1993. Energy and protein requirements of ruminants. CAB International, Wallingford, UK, An advisory manual prepared by the AFRC Technical Committee on Responses to Nutrients.

Anderson, J. 1935. Improvement of native cattle by selective breeding and herd management. Records of improved production of milk by the use of natural grazing only: experiments carried out at the Native Training Centre, Ngong. East African Agricultural Journal 1: 251-258.

Ayalew, W., Rischkowsky, B. R., King, J. M. and Bruns, E. 2003. Crossbreds did not generate more net benefits than indigenous goats in Ethiopian smallholdings. Agricultural Systems 76: 1137-1156.

Baker, R. L., Mugambi, J. M., Audho, J. O., Carles, A. B. and Thorpe, W. 2004. Genotype by environment interactions for productivity and resistance to gastro-intestinal nematode parasites in Red Maasai and Dorper sheep. Animal Science 79: 343-353.

Bebe, B. O. 2003. Herd dynamics of smallholder dairy in the Kenya highlands, Ph.D. thesis, Wageningen University.

Bebe, B. O., Udo, H. M. J., Rowlands, G. J. and Thorpe, W. 2003a. Smallholder dairy systems in the Kenya highlands: breed preferences and breeding practices. Livestock Production Science 82: 117-127.

Bebe, B. O., Udo, H. M. J., Rowlands, G. J. and Thorpe, W. 2003b. Smallholder dairy systems in the Kenya highlands: cattle population dynamics under increasing intensification. Livestock Production Science 82: 211-221.

Bosman, H. G., Moll, H. A. J. and Udo, H. M. J. 1997. Measuring and interpreting the benefits of goat keeping in tropical farm systems. Agricultural Systems 53: 349-372.

Chamberlain, A. 1993. Milk production in the tropics. Longman, Essex.

De Rensis, F. and Scaramuzzi, R. J. 2003. Heat stress and seasonal effects on reproduction in the dairy cow - a review. Theriogenology 60: 1139-1151.

Du Preez, J. H., Giesecke, W. H. and Hattingh, P. J. 1990. Heat stress in dairy cattle and other livestock under Southern African conditions. I. Temperature-humidity-index mean values during the four main seasons. Onderstepoort Journal of Veterinary Research 57: 77-87.

Economist. 2005. Leader. The key to trade and aid. The Economist, 4 June. pp. 13-14.

Faulkner, D. E. 1951. The improvement of cattle in Kenya with special reference to the indigenous types. Fellowship thesis, Royal College of Veterinary Surgeons, London.

Hulme, M., Doherty, R., Ngara, T., New, M. and Lister, D. 2001. African climate change: 1900-2100. Climate Research 17: 145-168. Ikiror, D. 2001 Heat stress in dairy cattle in Kenya. Ph.D. thesis, Georg-August University Cuvillier, Goettingen.

James, A. D. and Carles, A. B. 1996. Measuring the productivity of grazing and foraging livestock. Agricultural Systems 52: 271-291.

Johnson, H. D. 1965. Environmental temperature and lactation (with special reference to cattle). International Journal of Biometeorology 9: 103-116.

Johnson, H. D., Ragsdale, A. C., Berry, I. L. and Shanklin, M. D. 1963. Temperature-humidity effects including influence of acclimation in feed and water consumption of Holstein cattle. Research Bulletin of Missouri Agricultural Experimental Station no. 846.

Kahi, A. K., Thorpe, W., Nitter, G. and Baker, R. L. 2000. Crossbreeding for dairy production in the lowland tropics of Kenya. 1. Estimation of individual crossbreeding effects on milk production and reproductive traits and on cow live weight. Livestock Production Science 63: 39-54.

Kenya Dairy Development Project/Smallholder Dairy Project. 2004. Future of smallholder dairy in Kenya. About us. Breeding News special edition. Breeding Study Team International Livestock Research Institute, Nairobi.
Macfarlane, J. S. and Stevens, B. A. 1972. The effect of natural shade and spraying with water on the productivity of dairy cows in the tropics. Tropical Animal Health and Production 4: 249-253.

Maloo, S. H., Rowlands, G. J., Thorpe, W., Gettinby, G. and Perry, B. D. 2001a. A longitudinal study of disease incidence and case-fatality risks on small-holder dairy farms in coastal Kenya. Preventive Veterinary Medicine 52: 17-29.

Maloo, S. H., Thorpe, W., Kioo, G., Ngumi, P., Rowlands, G. J. and Perry, B. D. 2001b. Seroprevalences of vector-transmitted infections of small-holder dairy cattle in coastal Kenya. Preventive Veterinary Medicine 52: 1-16.

Margerison, J. K. 2003. A review of dairy heifer rearing and its effect on heifer performance, longevity, rearing costs and farm income. In Dairying, using science to meet consumer needs (ed. E. Kebreab, J. Mills and D. Beever), British Society of Animal Science occasional publication no. 29, pp. 1-35.

Mason, I. L. and Maule, J. P. 1960. The indigenous livestock of eastern and southern Africa. Commonwealth Agricultural Bureaux, Farnham Royal.

Muinga, R. W., Bimbuzi, S. and Mambo, L. C. 1998. Nutrient composition of locally available feedstuffs in coastal lowland Kenya. In Proceedings of sixth biennial Kenya Agricultural Research Institute scientific conference. pp. 287-293. Kenya Agricultural Research Institute, Nairobi.

Nicholson, C. F., Thornton, P. K., Mohammed, I., Muinga, R. W., Mwamachi, D. M., Elbasha, E. H., Staal, S. J. and Thorpe, W. 1999. Smallholder dairy technology in coastal Kenya. An adoption and impact study. International Livestock Research Institute, Nairobi.

Omore, A. O., McDermott, J. J., Muriuki, H. M. and Thorpe, W. 1998. Smallholder dairy herd management in Kenya. Paper presented at the seminar on dairy farm management, at the 25th International Dairy Congress, 21-24 September, Aarhus, Denmark. Kenya Smallholder Dairy Project, ILRI, Nairobi, http://www. smallholderdairy.org/

Omore, A., Muriuki, H., Kenyanjui, M., Owango, M. and Staal, S. 1999. The Kenya dairy sub-sector. A rapid appraisal. Smallholder Dairy Project, International Livestock Research Institute, Nairobi.

Parsons, D. J., Armstrong, A. C., Turnpenny, J. R., Matthews, A. M., Cooper, K. and Clark, J. A. 2001. Integrated models of livestock systems for climate change studies. 1. Grazing systems. Global Change Biology 7: 93-112.

Plaizier, J. C., Tanner, J. C., Omore, A. and McBride, B. 1999. Costs of extending calving intervals of dairy cows on small holder farms in Kenya. Journal of Dairy Science 82: (suppl.) 78.

Rockefeller Foundation. 1994. Strategic plan for a new CGIAR global livestock research institution. Strategic Planning Task Force, The Rockefeller Foundation, New York.

Rodriquez, L. A., Mekonnen, G., Wilcox, C. J., Martin, F. G. and Krienke, W. A. 1985. Effects of relative humidity, maximum and minimum temperature, pregnancy and stage of lactation on milk composition and yield. Journal of Dairy Science 68: 973-979.

Romney, D., Wambugu, M., Kaitho, R., Biwott, J., Chege, L., Omore, A., Staal, S., Wanjohi, P., Njubi, D. and Thorpe, W. 2005. Case study D: improving the efficiency of concentrate usage by smallholder dairy farmers in Kenya. In Participatory livestock research (ed. C. Conroy), pp. 185-195. ITDG Publishing, Rugby.

Scott, I. M., Johnson, H. D. and Hahn, G. L. 1983. Effect of programmed diurnal temperature cycles on plasma thyroxine level, body temperature, and feed intake of Holstein cows. International Journal Biometeorology 27: 47-62.

Staal, S. J., Waithaka, M., Njoroge, L., Mwangi, D. M., Njubi, D. and Wokabi, A. 2003. Costs of milk production in Kenya: estimates from Kiambu, Nakuru and Nyandarua districts. Smallholder Dairy Project, International Livestock Research Institute, Nairobi.

Taylor, V. J., Beever, D. E. and Wathes, D. C. 2003. Physiological adaptations to milk production that affect the fertility of high yielding 


\section{King, Parsons, Turnpenny, Nyangaga, Bakari and Wathes}

dairy cows. In Dairying, using science to meet consumer needs (ed. E. Kebreab, J. Mills and D. Beever), British Society of Animal Science, occasional publication no. 29, pp. 37-71.

Thatcher, W. W. 1974. Effects of season, climate, and temperature on reproduction and lactation. Journal of Dairy Science 57: 360-368.

Turnpenny, J. R. 1997. Potential impacts of climate change on the energy balance of UK Livestock. Ph.D. thesis University of Nottingham.

Turnpenny, J. R., McArthur, A. J., Clark, J. A. and Wathes, C. M. 2000a. Thermal balance of livestock 1. A parsimonious model. Agricultural and Forest Meteorology 101: 15-27.

Turnpenny, J. R., Wathes, C. M., Clark, J. A. and McArthur, A. J. 2000b. Thermal balance of livestock 2. Applications of a parsimonious model. Agricultural and Forest Meteorology 101: 29-52.

United Nations. 2005. The millenium development goals report. Department of Public Information, United Nations, New York.

Van der Valk, Y. S. 1992. Cost-price calculation of milk production under small scale zero grazing conditions. Working Paper NDDP/ M-45/242. Ministry of Livestock Development, Nairobi.

Waithaka, M. M., Ouma, E. A., Kariri, J. M., Ikongo, D. O. Herrero, M., Thornton, P. K. and Shepherd, K. D. 2003. System prototyping and impact assessment for sustainable alternatives in mixed farming systems in high potential areas of East Africa. Characterisation of Kilifi farming systems. Kenya Agricultural Research Institute/International Livestock Research Institute/World Agroforestry Centre, Nairobi.

Waters-Bayer, A. and Bayer, W. 2004. Research to alleviate poverty in the face of industrialisation of livestock production. In Responding to the livestock revolution - the role of globalisation and the implications for poverty alleviation (ed. E. Owen, T. Smith, M. A. Steele, S. Anderson, A. J. Duncan, M. Herrero, J. D. Leaver, C. K. Reynolds, J. I. Richards and J. C. Ku-Vera), British Society of Animal Science, occasional publication no. 33, pp. 191-208. Nottingham University Press.

Wathes, D. C., Taylor, V. J., Cheng, Z. and Mann, G. E. 2003 Follicle growth, corpus luteum function and their effects on embryo development in the post partum cow. Reproduction 61: (suppl.) 219-237.

Webster, A. J. F. 1993. Understanding the dairy cow. Blackwell, London.

Wood, P. D. P. 1969. Factors affecting the shape of the lactation curve in cattle. Animal Production 11: 307-316.

(Received 13 December 2005-Accepted 14 June 2006) 